[Denpun Kagaku, Vol.38, No. 1, p. 27 36 (1991)]

\title{
Preparation and Some Properties of a Novel Maltotetraose-Forming Enzyme of Pseudomonas saccharophila
}

\author{
Shoichi Kobayashi,* Hisashi OKemoto,** Kozo Hara,*** \\ Hitoshi HaShimoto** and Kazuhide YamaSATO*** \\ *National Food Research Institute, Ministry of Agriculture, Forestry and Fisheries \\ (2-1-2, Kannondai, Tsukuba 305, Japan) \\ **Ensuiko Sugar Refining Co., Ltd. \\ (13-46, Daikoku-cho, Tsurumi-ku, Yokohama 230, Japan) \\ ***Institute of Applied Microbiology, The University of Tokyo \\ (Yayoi 1-chome, Bunkyo-ku, Tokyo 113, Japan)
}

\begin{abstract}
It was found that Pseudomonas saccharophila produced a maltotetraose-forming enzyme. The enzyme was purified by ammonium sulfate fractionation and column chromatography on DEAE-Toyopearl 650M and Toyopearl HW-55s.

The activity recovery was $19 \%$ at the final step of the purification. The purified enzyme was homogeneous electrophoretically and its molecular weight was 62,000. The optimum pH and temperature were 6.7 and $55^{\circ} \mathrm{C}$, respectively. The enzyme was stable up to $40^{\circ} \mathrm{C}$ in the $\mathrm{pH}$ range of 5.5 to 10.5 for $1 \mathrm{hr}$, and thermostable in the presence of $2 \mathrm{mM} \mathrm{CaCl}_{2}$ up to $45^{\circ} \mathrm{C}$.

The isoelectric point of the enzyme was 4. 7. The enzyme activity was inhibited by metal ions such as $\mathrm{Ag}^{+}, \mathrm{Hg}^{2+}, \mathrm{Co}^{2+}, \mathrm{Cu}^{2+}, \mathrm{Fe}^{3+}, \mathrm{Al}^{3+}, \mathrm{Zn}^{2+}$, and enhanced by $\mathrm{Sr}^{2+}$.

The enzyme specifically produced maltotetraose from starch, did not act on glucose, maltose, maltotriose, and maltotetraose.

The enzyme action proceeded from non-reducing ends of the substrates and seemed to be difficult skipping over the branches of amylopectin.
\end{abstract}

Maltooligosaccharides $\left(\mathrm{G}_{3}-\mathrm{G}_{6}\right)$ have been used as reagents for research and as clinical reagents for the determination of serum amylase activity. ${ }^{1)} G_{5}$ has been used as a nutrient for calorie deprivation. ${ }^{2)}$ This oligosaccharide, as well as $\mathrm{G}_{3}, \mathrm{G}_{4}$ and $\mathrm{G}_{6}$ is highly soluble in water and produce clear viscous solutions which are palatable. Therefore, these compounds may potentially be of use as superior nutrients for infants and aged persons. The price of pure maltooligosaccharides is, however, extremely high, because of the difficulties encountered in producing them in a pure state. Birch and Etheridge separated a low molecular weight fraction (LMF) containing $\mathrm{G}_{1}-\mathrm{G}_{6}$ and a high molecular weight fraction (HMF) containing polymers higher than $G_{7}$ by ethanol fractionation. ${ }^{3}$ ) Both

Symbols, $G_{1}, G_{2}, G_{3}, G_{4}, G_{5}, G_{6} \ldots G_{10}$ are glucose, maltose, maltotriose, maltotetraose, maltopentaose, maltohexaose $\cdots$ maltodecaose. fractions were used in feeding experiments with rats. Upwards trends of most tissue lipids and weight gains were observed to correlate with the increasing molecular weight fraction in the order of $\mathrm{G}_{1}<\mathrm{LMF}<\mathrm{HMF}$.

Martin and Young reported that $\mathrm{G}_{3}$ was highly digestible and usable as a nutrient in comparison to $\mathrm{G}_{1}{ }^{4}{ }^{\text {) }}$

Recently in Japan, physiologically active (or bio-active) food is being developed at a rapid pace. In the course of the development it is known that maltooligosaccharides such as $\mathrm{G}_{3}$, $\mathrm{G}_{4}, \mathrm{G}_{5}$, and $\mathrm{G}_{6}$ have antibiotic properties against plant disease bacteria such as Erwinia carotovor $a^{5)}$ and they also act as specific growth depressors of detrimental bacteria such as Clostridium perfringens in the intestines. ${ }^{6)}$

Several reports have been published on the production of maltooligosaccharides such as $G_{2}$, $\mathrm{G}_{3}, \mathrm{G}_{4}, \mathrm{G}_{5}$, etc., from starch. $\mathrm{G}_{2}$ production from 
starch has been widely studied using plant $\beta$ amylases. As for $\mathrm{G}_{3}-\mathrm{G}_{6}, \mathrm{G}_{3}$-forming amylases were discovered in Streptomyces griseus NA46877) and Bacillus subtilis, ${ }^{8)}$ and Bacillus circulans $^{9}$ (its enzyme also forms $\mathrm{G}_{5}$ ), and $\mathrm{G}_{5}$-forming amylases in Bacillus licheniformis ${ }^{10}$ and Pseudomonas species. ${ }^{11}$ Yoshigi et al. found that $G_{5}$ was accumulated in the culture broth of Bacillus cereus NY-14. ${ }^{12)} \quad \mathrm{G}_{6}$-forming amylases were discovered in Aerobacter aerogenes (Klebsiella pneumoniae), ${ }^{13)}$ Bacillus circulans, ${ }^{14,15)}$ and Bacillus subtilis. ${ }^{16)}$

It was reported that a $\mathrm{G}_{4}$-forming amylase was produced by Pseudomonas stutzeri. ${ }^{17}$ The objective of this study was finding other bacteria which produce more stable $\mathrm{G}_{4}$-forming amylase than that of Pseudomonas stutzeri.

Pseudomonas saccharophila was found to produce that enzyme.

\section{MATERIALS AND METHODS}

Materials. Soluble starch GR was purchased from Merck. Reduced soluble starch was prepared by reducing soluble starch with sodium borohydride (pure grade, Wako Pure Chemical Ind., Ltd.), by a modification of the method of Kainuma et al. ${ }^{11,18)}$ All other chemicals used were commercially available and of chemically pure grade.

Purification of the enzyme. Pseudomonas saccharophila (IAM 1504) was cultured, using a rotary shaker, in a liquid medium containing $1.0 \%$ soluble starch, $1 \%$ polypeptone (Daigoeiyoukagaku, Osaka, Japan), $0.1 \% \mathrm{KH}_{2} \mathrm{PO}_{4}$, $0.28 \% \mathrm{~K}_{2} \mathrm{HPO}_{4}, \mathrm{pH} 7.0$ in an Erlenmeyer flask for $48 \mathrm{hr}$ at $30^{\circ} \mathrm{C}$. The cells were removed by centrifugation at $10,000 \mathrm{rpm}$ for $15 \mathrm{~min}$ at $4^{\circ} \mathrm{C}$. The supernatant was fractionated by ammonium sulfate precipitation. The fraction, which precipitated between 0.3 to 0.5 ammonium sulfate saturation, was collected and dissolved in a $10 \mathrm{mM}$ phosphate buffer solution ( $\mathrm{pH} 7.0)$.

The enzyme solution was dialyzed against the same buffer solution at $4^{\circ} \mathrm{C}$ for $24 \mathrm{hr}$. After removal of insoluble materials by centrifugation, the dialyzed enzyme was chromatographed on a DEAE-Toyopearl 650M (Tosoh Co., Ltd.) column $(26.4 \times 420 \mathrm{~mm})$, which was eluted using a $10 \mathrm{mM}$ phosphate buffer solution $(\mathrm{pH}$ 7.0) and then using a linear gradient of $0(1 l)$ to $0.5 \mathrm{M}$ sodium chloride $(1 l)$ in the same buffer solution. Elution was performed at the rate of $200 \mathrm{ml} / \mathrm{hr}$.

The concentrated enzyme fraction was rechromatographed on a Toyopearl $650 \mathrm{M}$ column $(1.6 \times 100 \mathrm{~mm})$ using a linear gradient of 0 $(200 \mathrm{ml})$ to $0.3 \mathrm{M}$ sodium chloride $(200 \mathrm{ml})$ at a flow rate of $40 \mathrm{ml} / \mathrm{hr}$.

The concentrated enzyme from the 2 nd chromatography was chromatographed twice using Toyopearl HW-55s column $(1.6 \times 100 \mathrm{~mm})$ at a flow rate of $9.5 \mathrm{ml} / \mathrm{hr}$ with a $10 \mathrm{~mm}$ phosphate buffer solution ( $\mathrm{pH} \mathrm{7.0).} \mathrm{Pure} \mathrm{frac-}$ tions, which were checked by disc gel electrophoresis, were collected to obtain the pure enzyme solution $(75 \mathrm{IU} / \mathrm{ml}$ in $10 \mathrm{mM}$ phosphate buffer, pH 7.0).

Determination of the $G_{4}$-forming enzyme activity. Half a milliliter of a $2 \%$ reduced starch solution, $0.4 \mathrm{ml}$ of $0.1 \mathrm{M}$ phosphate buffer $(\mathrm{pH} 7.0$ ) and $0.1 \mathrm{ml}$ of the enzyme solution were mixed, followed by incubation at $30^{\circ} \mathrm{C}$. An aliquot of the reaction mixture was periodically removed and the reducing sugar formed was determined by the Somogyi-Nelson method. ${ }^{19)}$ One unit was defined as the amount of $1 \mu \mathrm{mol} \mathrm{G} \mathrm{G}_{4}$ liberated under the above conditions.

Paper chromatography and autoradiography. Ten to fifty $\mu$ l of the reaction mixture was spotted on a sheet of filter paper (Toyo Roshi No. 50). The paper was then irrigated twice in the ascending mode with a solvent system of 1-butanol : pyridine : water $(6: 4: 4$, $\mathrm{v} / \mathrm{v}$ at $60^{\circ} \mathrm{C}$. After the irrigation, the chromatogram was treated with glucoamylase ${ }^{20)}$ and then stained by the silver nitrate dip method. ${ }^{21)}$ In order to examine the action of the enzyme on maltooligosaccharides, two-dimensional paper chromatography was performed by the method of Kainuma and French, ${ }^{20)}$ using $50 \mu \mathrm{l}$ each of a standard series of maltooligosaccharides.

A standard series of maltooligosaccharides was prepared by mixing $1 \mathrm{~g}$ of $\alpha$-cyclodextrin, $1 \mathrm{~g}$ of maltose and 150 THU of cyclodextrin glucanotransferase (macerans enzyme), adjusting the po to 6.0 (no addition of buffer solution), followed by reaction at $40^{\circ} \mathrm{C}$ for $17 \mathrm{hr}$. The 
reaction mixture $(100 \mathrm{ml})$ was stood in a boiling bath for $10 \mathrm{~min}$ to inactivate the enzyme and then insoluble material was removed by centrifugation. The supernatant was used as the standard.

A two-dimensional autoradiogram was prepared in the same manner except that a ${ }^{14} \mathrm{C}$ reducing end-labelled maltooligosaccharide series $^{22}$ was applied and irrigation was performed 3 times. The dried chromatogram was put into contact with a sheet of X-ray film (Fuji $\mathrm{X}$-ray film, RX, $25.4 \times 30.5 \mathrm{~cm}$ ), followed by exposure for 2 weeks.

Electrophoresis and molecular weight determination. Polyacrylamide gel electrophoresis (PAGE) in the absence of SDS was performed by using $7.5 \%$ gel. SDS-PAGE was performed by the method of Weber and Osborn, ${ }^{23}$ using $5 \%$ gel and a series of proteins of known molecular weights (Seikagaku Kogyo Co., Ltd., Japan ; SDS-PAGE Marker I, thermostable RNA polymerase $B$ ). The isoelectric point of the enzyme was measured by polyacrylamide gel electrofocusing as described by Wrigley ${ }^{24)}$ using Ampholine, with a $\mathrm{pH}$ range of 3.5 to 10 , as a carrier.

Measurement of mutarotation of the $G_{4}$ formed. The reaction was started by adding $200 \mu \mathrm{l}$ of the purified enzyme ( 3 IU) to $4 \mathrm{ml}$ of $1 \%$ soluble starch in $0.1 \mathrm{M}$ phosphate buffer $(\mathrm{pH} 7.0)$ in a jacketed cell $(10 \times 50 \mathrm{~mm})$ at $40^{\circ} \mathrm{C}$, with an automatic digital polarimeter (Nihon Bunko Co., Ltd.; DIP-181), and the change in optical rotation was recorded. After $60 \mathrm{~min}, 5 \mathrm{mg}$ of sodium carbonate was added and the mutarotation was measured.

Determination of the optimum reaction conditions and enzyme stability. To determine the optimum $\mathrm{pH}$ of the reaction, the reducing value was determined after $10 \mathrm{~min}$ incubation at $40^{\circ} \mathrm{C}$. The reaction mixture consisted of $0.5 \mathrm{ml}$ of a $2 \%$ reduced soluble starch solution, $0.4 \mathrm{ml}$ of a $0.1 \mathrm{M}$ buffer solution of different $\mathrm{pH}$ values and $0.1 \mathrm{ml}$ of the enzyme solution $(0.3 \mathrm{IU} / \mathrm{ml}$ in water).

For determination of the $\mathrm{pH}$ stability, $0.1 \mathrm{ml}$ of the enzyme solution was mixed with $0.9 \mathrm{ml}$ of a $10 \mathrm{mM}$ buffer solution of various $\mathrm{pH}$ values

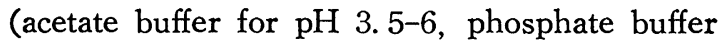
for $\mathrm{pH} 6-8$, and sodium carbonate/bicarbonate buffer for $\mathrm{pH}$ 9-11), followed by standing for $60 \mathrm{~min}$ at $30^{\circ} \mathrm{C}$. After this treatment, $0.5 \mathrm{ml}$ of $2 \%$ reduced soluble starch, $0.4 \mathrm{ml}$ of $0.1 \mathrm{M}$ phosphate buffer ( $\mathrm{pH} \mathrm{7.0)}$ and $0.1 \mathrm{ml}$ of the treated enzyme solution were mixed and incubated for $10 \mathrm{~min}$ at $40^{\circ} \mathrm{C}$, and then the remaining activity was determined.

The optimum temperature of the reaction was determined by incubating $0.1 \mathrm{ml}$ of the enzyme solution with $0.4 \mathrm{ml}$ of a $0.1 \mathrm{M}$ phosphate buffer solution ( $\mathrm{pH} \mathrm{7.0)}$ and $0.5 \mathrm{ml}$ of a $2 \%$ reduced soluble starch solution for $10 \mathrm{~min}$ at various temperatures.

For determination of the thermostability, 0.1 $\mathrm{ml}$ of the enzyme solution (0.3 IU) was incubated with $0.4 \mathrm{ml}$ of a $0.1 \mathrm{M}$ acetate buffer solution $(\mathrm{pH} \mathrm{6.0)}$ at various temperatures for $30 \mathrm{~min}$, and then $0.5 \mathrm{ml}$ of a $2 \%$ reduced soluble starch solution was added and the reducing sugar formed was determined after incubation for a further $10 \mathrm{~min}$ at $40^{\circ} \mathrm{C}$.

To determine the effect of calcium ions on the thermostability, the enzyme in $0.1 \mathrm{M}$ acetate buffer ( $\mathrm{pH} \mathrm{6.0)}$ was incubated for $10 \mathrm{~min}$ at various temperatures in the presence and absence of $2 \mathrm{mM}$ calcium chloride, and then the remaining activity was determined.

Effects of various metal ions and chemicals. To determine the effects of various metal ions and chemicals, $0.1 \mathrm{ml}$ of the dialyzed enzyme solution ( $0.3 \mathrm{IU}$ ) was mixed with $0.4 \mathrm{ml}$ of a $0.1 \mathrm{M}$ acetate buffer solution containing various metal ions or chemicals and, after standing for $30 \mathrm{~min}$ at $30^{\circ} \mathrm{C}, 0.5 \mathrm{ml}$ of a $2 \%$ reduced soluble starch solution was added to react for 10 $\min$ at $40^{\circ} \mathrm{C}$. The final concentration of the various metal ions and chemicals was $1 \mathrm{~mm}$.

Relative rate of the enzyme reaction on various substrates. A reaction mixture, consisting of $0.5 \mathrm{ml}$ of a $2 \%$ substrate solution, $0.4 \mathrm{ml}$ of a $0.1 \mathrm{M}$ phosphate buffer solution and $0.1 \mathrm{ml}$ of the enzyme solution (0.3 IU), was incubated for $10 \mathrm{~min}$ at $40^{\circ} \mathrm{C}$ and then the reducing sugar formed was determined.

\section{RESULTS}

Purification of the enzyme. At the ammonium sulfate fractionation step, the recovery of $\mathrm{G}_{4}$-forming enzyme activity was $95 \%$. Seventy 


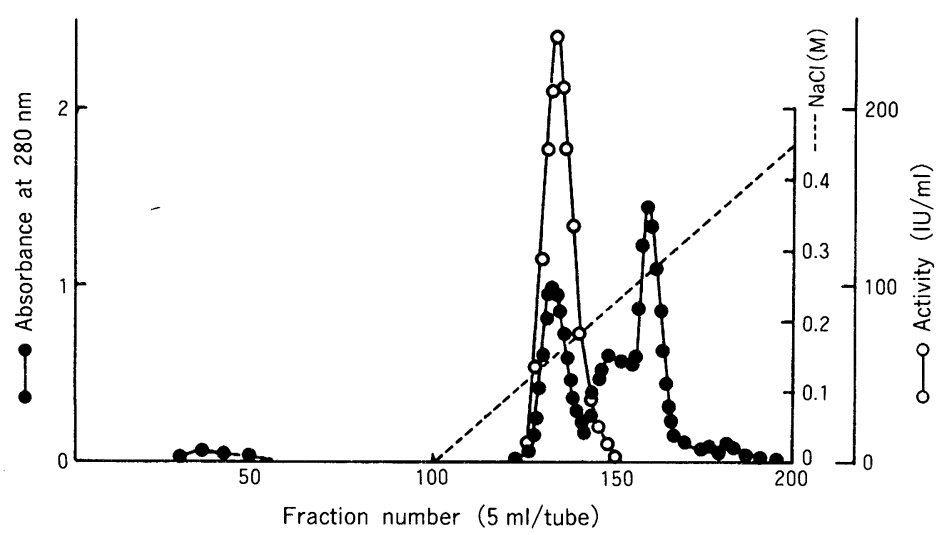

Fig. 1. First DEAE-Toyopearl $650 \mathrm{M}$ column chromatography for the $\mathrm{G}_{4}$-forming enzyme purification.

The fractions having the activity ( $5 \mathrm{ml} /$ fraction) in tube numbers $127-142$ were collected, dialyzed and concentrated to $15 \mathrm{ml}$ for the second column chromatography.

percent of the enzyme was recovered from a DEAE-Toyopearl $650 \mathrm{M}$ column at the concentration of $0.1-0.2 \mathrm{M}$ sodium chloride (Fig. 1). Subsequently, on the rechromatography on a DEAE-Toyopearl $650 \mathrm{M}$ column, only one symmetrical protein peak associated with the enzyme activity was obtained. The enzyme was further purified by gel filtration on Toyopearl HW-55s twice (Fig. 2). At this stage, the enzyme preparation gave a single band on disc gel electrophoresis (ref. Fig. 11). A summary of the purification is given in Table 1. At the final stage, the enzyme was purified about 150 -fold and had a specific activity of $434 \mathrm{IU} / \mathrm{mg}$. The activity recovery was $19 \%$.

Properties of the enzyme. Figure 3 shows the optimum $\mathrm{pH}$ and $\mathrm{pH}$ stability of the enzyme. The optimum $\mathrm{pH}$ of the enzyme was 6.7 , and the enzyme retained more than $90 \%$ of its activity between $\mathrm{pH} 5.5$ and 10.5.

Figure 4 shows the optimum reaction temperature and thermostability of the enzyme. The optimum temperature of the enzyme was $55^{\circ} \mathrm{C}$. As to thermostability, the enzyme was stable up to $40^{\circ} \mathrm{C}$, and in the presence of $2 \mathrm{mM}$ calcium chloride the stability was increased by $5^{\circ} \mathrm{C}$ (Fig. 5).

Figure 6 shows molecular weight determination of the enzyme by SDS-PAGE. The electrophoresis was carried out using thermostable

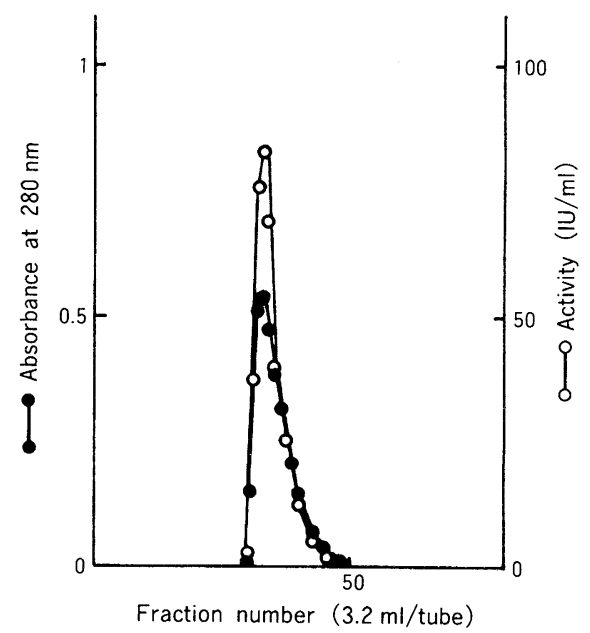

Fig. 2. The second Toyopearl HW-55s column chromatography for the $\mathrm{G}_{4}$-forming enzyme purification.

The fractions having the activity $(9.5 \mathrm{ml} /$ fraction) in tube numbers 30-33 were collected and concentrated, and the concentrated enzyme solution was applied on the second gel filtration column.

RNA polymerase $B$ as a standard, which has five subunits (M.W.: $z, 39,000 ; \alpha, 42,000 ; \chi$, 100,$\left.000 ; \beta, 140,000 ; \beta^{\prime}, 180,000\right)$.

The molecular weight of the enzyme was estimated on SDS-PAGE to be 62,000 . The pure enzyme preparation gave a single protein band which exhibited amylase activity, on the zymogram. The isoelectric point was 4.7 . The 
Table 1. Purification scheme of the $\mathrm{G}_{4}$-forming enzyme.

\begin{tabular}{lccccc}
\hline \multicolumn{1}{c}{ Step } & $\begin{array}{c}\text { Volume } \\
(\mathrm{ml})\end{array}$ & $\begin{array}{c}\text { Total } \\
\text { activity } \\
(\mathrm{IU})\end{array}$ & $\begin{array}{c}\text { Total } \\
\text { protein } \\
(\mathrm{mg})\end{array}$ & $\begin{array}{c}\text { Specific } \\
\text { activity } \\
(\mathrm{IU} / \mathrm{mg} \text { protein })\end{array}$ & $\begin{array}{c}\text { Recovery } \\
(\%)\end{array}$ \\
\hline Culture sup & 810 & 10686 & 3504 & 3.05 & 100 \\
(NH $\left._{4}\right)_{2} \mathrm{SO}_{4}$ ppta) & 50 & 10149 & 186 & 54.6 & 95 \\
DEAE-Toyopearl 650M (1st) & 70 & 7530 & 21.9 & 344 & 70 \\
DEAE-Toyopearl 650M (2nd) & 24 & 7088 & 18.0 & 394 & 66 \\
Toyopearl HW-55s (1st) & 12 & 3787 & 8.50 & 446 & 35 \\
Toyopearl HW-55s (2nd) & 27 & 2039 & 4.70 & 434 & 19 \\
\hline
\end{tabular}

a) 0.3-0.5 saturated $\left(\mathrm{NH}_{4}\right)_{2} \mathrm{SO}_{4}$.

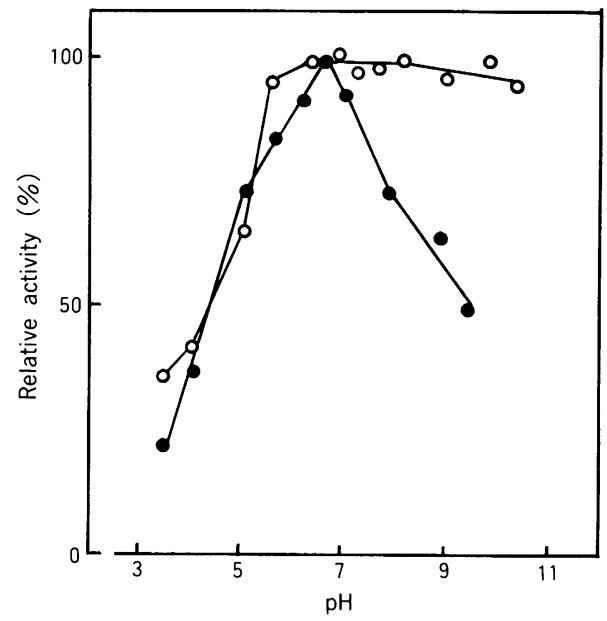

Fig. 3. Optimum $\mathrm{pH}$ and $\mathrm{pH}$ stability of the $\mathrm{G}_{4^{-}}$ forming enzyme.

--๑, optimum $\mathrm{pH} ; \bigcirc-\bigcirc, \mathrm{pH}$ stability. $\mathrm{pH}$ 3.5-6, acetate buffer; $\mathrm{pH}$ 6-8, phosphate buffer; $\mathrm{pH} 9-11$, carbonate/bicarbonate buffer.

molecular weight of the enzyme was also estimated as 61,000 by using gel column chromatography of Toyopearl HW-55s.

Table 2 shows the effects of various metal ions and chemicals on the enzyme activity. The enzyme action was slightly enhanced by $\mathrm{Sr}^{2+}$, but was not affected by $\mathrm{Ca}^{2+}$ and $\mathrm{Rb}^{+}$at $1 \mathrm{mM}$. On the other hand, the activity was inhibited by $\mathrm{Mn}^{2+}, \mathrm{Zn}^{2+}, \mathrm{Al}^{3+}, \mathrm{Fe}^{3+}, \mathrm{Cu}^{2+}, \mathrm{Co}^{2+}, \mathrm{Ag}^{+}$and $\mathrm{Hg}^{2+}$ in this order. At $1 \mathrm{mM}$, iodoacetamide, SDS and L-cysteine did not affect the activity but $p$-chloromercuribenzoic acid considerably affected it.

Hydrolysis of various substrates. The mutarotation of the product from soluble starch during the enzyme action was examined. Fig-

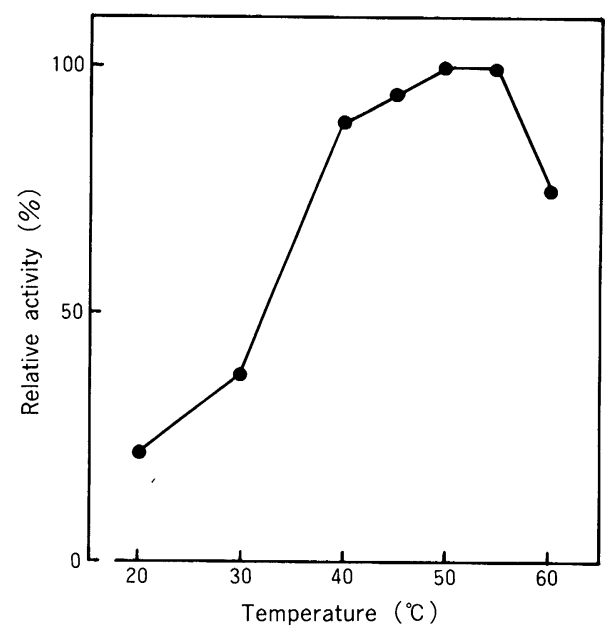

Fig. 4. Optimum temperature of the $\mathrm{G}_{4}$-forming enzyme.

ure 7 shows the rate of the change in optical rotation with time. A decrease in the optical rotation after the addition of sodium carbonate was observed. This suggests that the hydrolysis product is of the $\alpha$-configuration. The relative initial rate of the enzyme reaction on various substrates was determined and the results are presented in Table 3. Soluble starch, waxy starch (amylopectin), reduced soluble starch, and oyster glycogen were rapidly hydrolyzed, but pullulan, $\alpha$ - and $\beta$-cyclodextrins were not hydrolyzed at all.

Figure 8 shows the action of the enzyme on soluble starch. The enzyme specifically produced $\mathrm{G}_{4}$ from soluble starch during the reaction, but it was quite difficult for the action to proceed over the branching points of branched substrates such as amylopectin, because that $\beta$-limit dextrin was resistant to the action as 


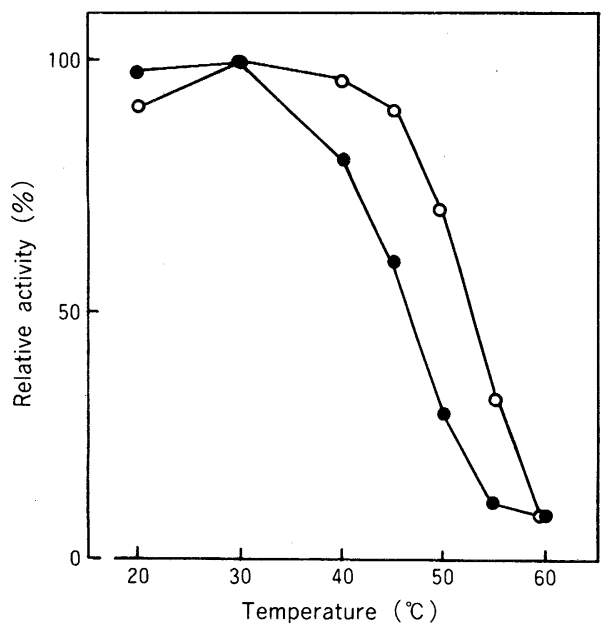

Fig. 5. Effect of $\mathrm{Ca}^{2+}$ on the thermostability of the $\mathrm{G}_{4}$-forming enzyme.

--๑, without $\mathrm{Ca}^{2+} ; \mathrm{O}-\mathrm{O}$, with $\mathrm{Ca}^{2+}$.

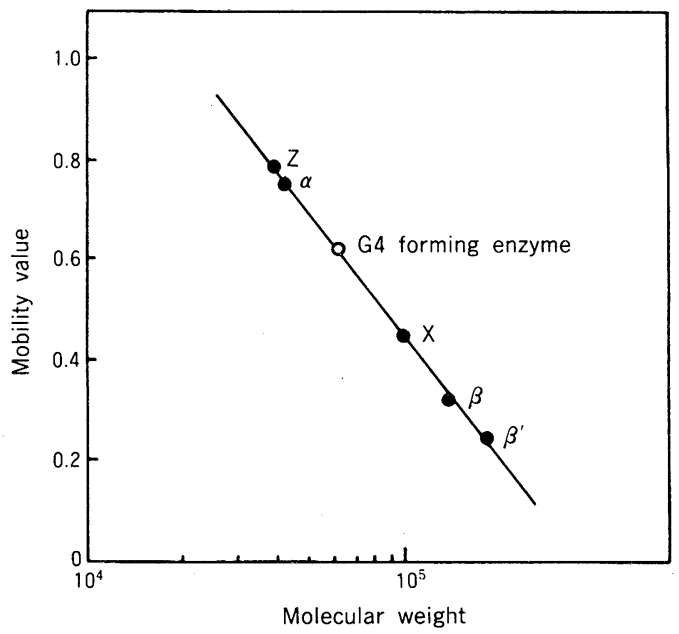

Fig. 6. Molecular weight determination of the $\mathrm{G}_{4}$ forming enzyme by SDS-polyacrylamide gel electrophoresis.

SDS-polyacrylamide gel electrophoresis was carried out using thermostable RNA polymerase $\mathrm{B}$ as a standard (M. W. : z, 39, $000 ; \alpha, 42,000 ; \chi, 100,000$; $\left.\beta, 140,000 ; \beta^{\prime}, 180,000\right)$.

in Table 3.

Figure 9 shows a two-dimensional paper chromatogram illustrating the action of the enzyme on maltooligosaccharides. $G_{1}, G_{2}, G_{3}$, and $\mathrm{G}_{4}$ were not converted to any other saccharide.

Through the action, $G_{1}+G_{4}$ were formed from $G_{5}$, and $G_{2}+G_{4}$ from $G_{6}, G_{3}+G_{4}$ from
Table 2. Effects of metal ions and chemicals on the enzyme activity.

\begin{tabular}{|c|c|}
\hline Material (1 mM) & Residual activity (\%) \\
\hline None & 100 \\
\hline $\mathrm{SrCl}_{2}$ & 114 \\
\hline $\mathrm{MgCl}_{2}$ & 108 \\
\hline $\mathrm{Li}_{2} \mathrm{SO}_{4}$ & 105 \\
\hline $\mathrm{CaCl}_{2}$ & 99 \\
\hline $\mathrm{RbCl}$ & 99 \\
\hline $\mathrm{MnSO}_{4}$ & 58 \\
\hline $\mathrm{ZnSO}_{4}$ & 29 \\
\hline $\mathrm{Al}_{2}\left(\mathrm{SO}_{4}\right)_{2}$ & 19 \\
\hline $\mathrm{FeCl}_{3}$ & 5 \\
\hline $\mathrm{CuSO}_{4}$ & 3 \\
\hline $\mathrm{CoCl}_{2}$ & 1 \\
\hline $\mathrm{AgNO}_{3}$ & 0 \\
\hline $\mathrm{HgCl}_{2}$ & 0 \\
\hline L-Cysteine & 93 \\
\hline $\mathrm{CH}_{2} \mathrm{ICONH}_{2}$ & 89 \\
\hline SDS & 89 \\
\hline$\left.p-\mathrm{CMB}(0.4 \mathrm{mM})^{\mathrm{a}}\right)$ & 37 \\
\hline
\end{tabular}

a) $p$-Chloromercuribenzoic acid.

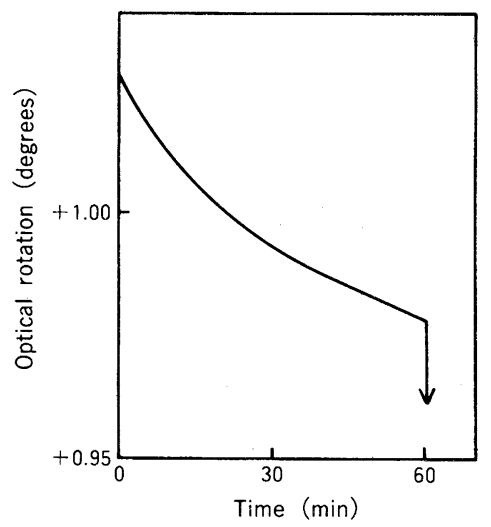

Fig. 7. Mutarotation of the product of the $\mathrm{G}_{4}$-forming enzyme action on soluble starch.

Table 3. Relative reaction rate of the enzyme reaction on various substrates.

\begin{tabular}{lc}
\hline $\begin{array}{c}\text { Substrate } \\
\text { (final concentration 1\%) }\end{array}$ & $\begin{array}{c}\text { Relative reaction rate } \\
(\%)\end{array}$ \\
\hline Soluble starch & 100 \\
Waxy starch (amylopectin) & 95 \\
Reduced soluble starch & 90 \\
Glycogen (oyster) & 67 \\
$\beta$-Limit dextrin (glycogen) & 0 \\
Pullulan & 0 \\
$\alpha$-Cyclodextrin & 0 \\
$\beta$-Cyclodextrin & 0 \\
\hline
\end{tabular}




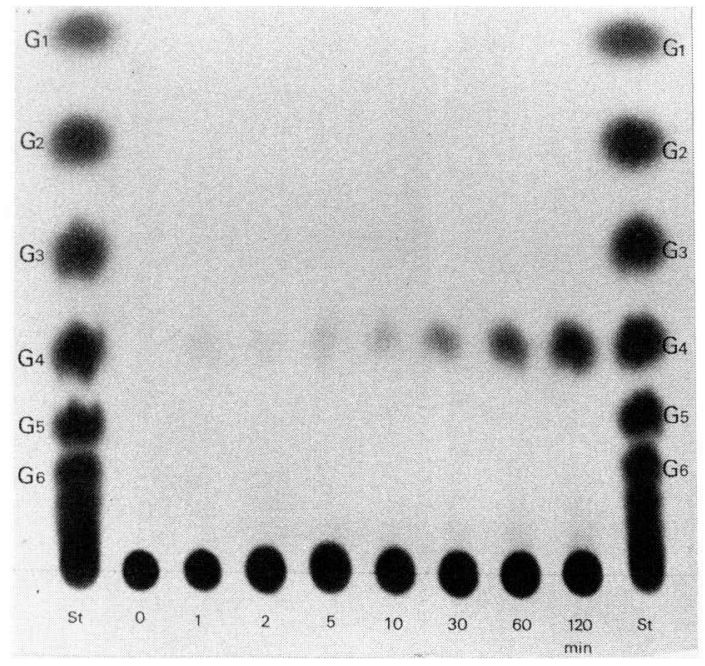

Fig. 8. Paper chromatogram showing the time course of $\mathrm{G}_{4}$-forming enzyme action on soluble starch.

A mixture composed of final $1 \%$ concentration of soluble starch, enzyme concentration $5 \mathrm{IU} / \mathrm{g}$ substrate and final $10 \mathrm{mM}$ phosphate buffer $(\mathrm{pH} \mathrm{7.0)}$ was reacted at $30^{\circ} \mathrm{C}$, and periodically sampled $(15 \mu \mathrm{l})$ to spot on the paper.

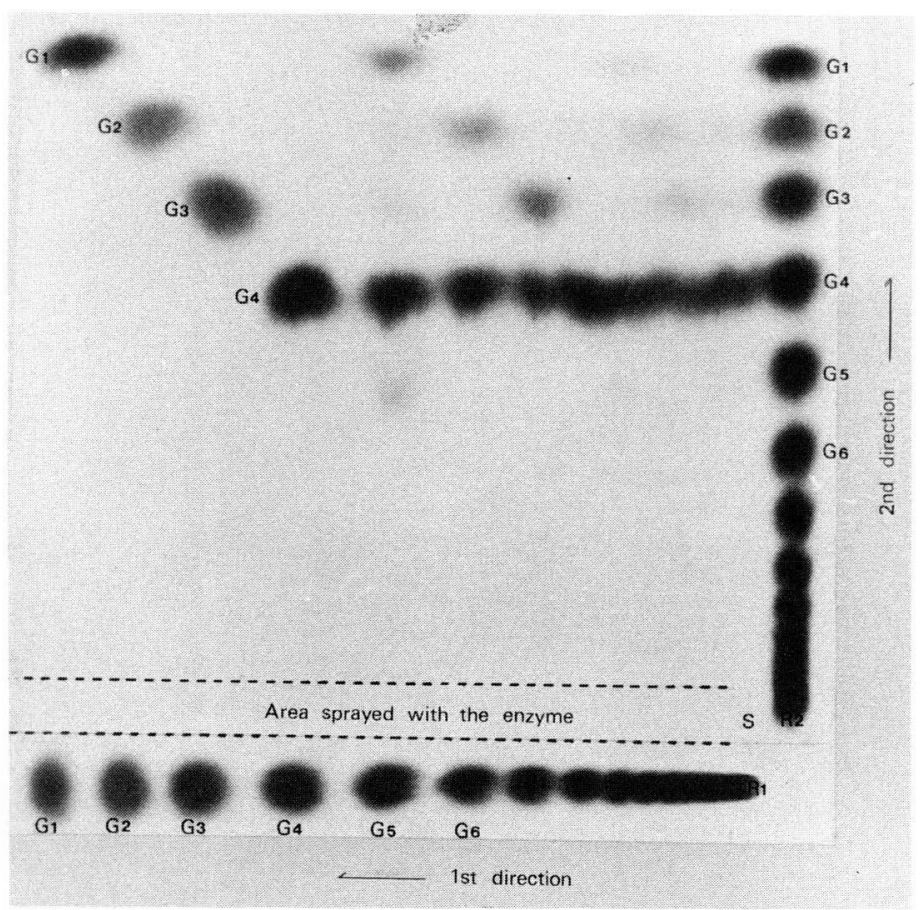

Fig. 9. Two-dimensional paper chromatogram showing the action pattern of the $\mathrm{G}_{4}$-forming enzyme on maltooligosaccharides.

$R_{1}$ and $R_{2}$ denote reference series of maltooligosaccharides for the first and second directions of the chromatogram. $\mathrm{S}$ is the application point of maltooligosaccharide series. The amount applied was $50 \mu 1$ of a standard maltooligosaccharide series solution (sugar concentration, 2\%). After irrigation in the first direction, the lower side of the chromatogram containing the $\mathrm{R}_{1}$ channel was cut off for reference. The remaining $\mathrm{S}$ channel was uniformally sprayed with $10 \mathrm{ml}$ of a dilute enzyme solution (100 $\mu 1$ of the original enzyme solution, $75 \mathrm{IU} / \mathrm{ml}+10 \mathrm{ml}$ of water). After allowing the enzyme action to proceed on the paper in a moist chamber at $45^{\circ} \mathrm{C}$ for $1 \mathrm{hr}$, the chromatogram was dried in an oven $\left(100^{\circ} \mathrm{C}\right)$ for $15 \mathrm{~min}, \mathrm{R}_{2}$ was applied and then the chromatogram was irrigated again in the second direction. 


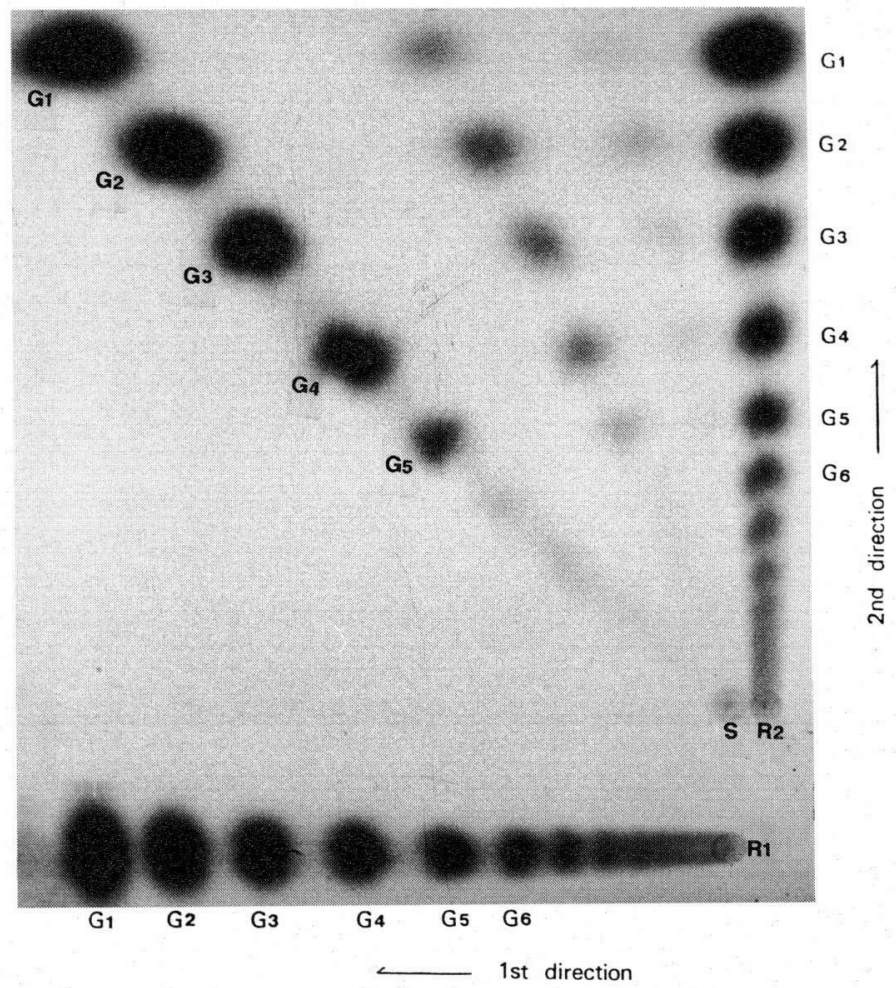

Fig. 10. Two-dimensional autoradiogram showing the action pattern of the $\mathrm{G}_{4}$-forming enzyme on maltooligosaccharides.

The experimental conditions were the same as in Fig. 9, except that applied sample was $100 \mu \mathrm{l}$ of a ${ }^{14} \mathrm{C}$ labelled maltooligosaccharide series.

(1)

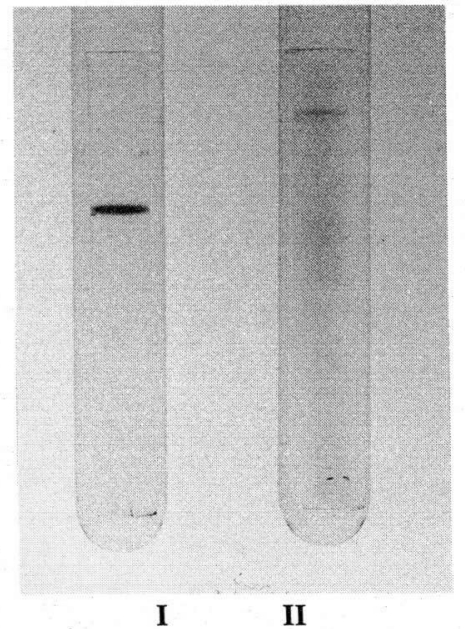

(2)

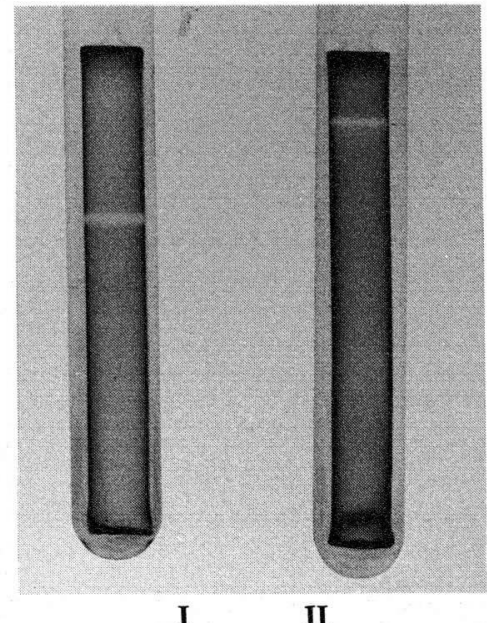

Fig. 11. Comparison of Pseudomonas saccharophila and stutzeri $\mathrm{G}_{4}$-forming enzyme on disc gel electrophoresis.

$\mathrm{I}$, Pseudomonas saccharophila $\mathrm{G}_{4}$-forming enzyme; II, Pseudomonas stutzeri $\mathrm{G}_{4}$-forming enzyme. (1), Polyacrylamide disc gel electrophoresis (stained with Coomassie blue); (2), Zymogram (stained with an iodine solution). 
Table 4. Comparison of $\mathrm{G}_{4}$-forming enzyme from Ps. saccharophila and Ps. stutzeri.

\begin{tabular}{lcc}
\hline & Ps. saccharophila & Ps. stutzeri \\
\hline Action pattern & Exo & Exo \\
Anomer configuration & $\alpha$ & $\alpha$ \\
Optimum pH & 6.7 & 6.5 \\
pH stability & $5.5 \sim 10.5$ & $6.5 \sim 11$ \\
Optimum temperature & $50 \sim 55^{\circ} \mathrm{C}$ & $45^{\circ} \mathrm{C}$ \\
Thermostability & & \\
$\quad$ without $\mathrm{Ca}^{2+}$ & $<40^{\circ} \mathrm{C}$ & $<30^{\circ} \mathrm{C}$ \\
$\quad$ with $\mathrm{Ca}^{2+}$ & $<45^{\circ} \mathrm{C}$ & - \\
Molecular weight & 62,000 & 57,000 \\
Isoelectric point & 4.7 & 5.3 \\
Inactivated by & $\mathrm{Hg}^{2+}, \mathrm{Ag}^{+}, \mathrm{Co}^{2+}, \mathrm{Cu}^{2+}, \mathrm{Fe}^{3+}$ & $\mathrm{Hg}^{2+}, \mathrm{Cu}^{2+}$ \\
\hline
\end{tabular}

$\mathrm{G}_{7}$, and $\mathrm{G}_{4}+\mathrm{G}_{4}$ from $\mathrm{G}_{8}$, respectively.

Figure 10 shows a two-dimensional autoradiogram illustrating the action of the enzyme on maltooligosaccharides which were ${ }^{14} \mathrm{C}$ labelled at each reducing end.

A radioactive fragment of $G_{1}$ was formed from $G_{5}$, and $G_{2}$ from $G_{6}, G_{3}$ from $G_{7}, G_{4}$ from $\mathrm{G}_{8}, \mathrm{G}_{1}$ from $\mathrm{G}_{9}$ and so on through the action of the enzyme on the paper.

From the results, the action of the $\mathrm{G}_{4}$-forming enzyme can proceed from the non-reducing end of the substrates.

\section{DISCUSSION}

The $\mathrm{G}_{4}$-forming enzyme hydrolyzes substraingtes, seems to hardly skip over the branchpoints of branched substrates such as amylopectin and glycogen, to specifically produce $\mathrm{G}_{4}$ during the reaction.

It will be useful to determine the degradation limit of a branched substrate with the enzyme and the length of the branches on the stem of substrates. The details of the action of the enzyme on branched substrates will be reported elsewhere.

As for the production of $\mathrm{G}_{4}$, in the case of using amylopectin, addition of pullulanase or other kinds of debranching enzymes is necessary to enhance the yield. On the contrary, without debranching enzyme, it will be quite effective to separate $G_{4}$ from the reaction mixture of amylopectin by precipitating with organic solvents such as ethanol, acetone and so on and by use of ultra filtration membrane or a membrane reactor, because the reaction mixture contains $\mathrm{G}_{4}$ and large molecular weight of dextrins.

The action of the novel $\mathrm{G}_{4}$-forming enzyme (saccharophila enzyme) is quite similar to that of the previously reported $\mathrm{G}_{4}$-forming enzyme of Pseudomonas stutzeri, ${ }^{17)}$ but it is considerably different from that of stutzeri enzyme in the following respects: saccharophila enzyme is more stable than stutzeri enzyme on $\mathrm{pH}$ and temperature; molecular weight of saccharophila enzyme is larger than that of stutzeri enzyme; and their isoelectric points are quite different from each other. Consequently, the mobility on disc gel electrophoresis is different as shown in Fig. 11. The properties of both enzymes are summarized in Table 4.

\section{REFERENCES}

1) N. SaIto: Denpun Kagaku, 29, 153-160 (1982).

2) G. M. BERLYNE, E. M. BOOTH, R. A. L. BREWIS, N. P. MALLICK and P. J. SIMONS : Lancet, 1, 689-692 (1969).

3) G. G. BIRCH and I. J. ETHERIDGE : Stärke, 25, 235-238 (1973).

4) A. F. M. MARTIN and F. G. Young : Nature, 215, 885-886 (1967).

5) H. Kondo, T. HoNke, R. HASEgawa, T. SHIMODA and S. NAKAMURA : J. Antibiot., 28, 157-160 (1975).

6) M. Sugahara, M. TAKeUCHI, T. NAKaKuKI and T. MitsuOKA : J.Jpn. Soc. Nutr. Food Sci., 
42, 123-127 (1989).

7) K. WAKo, C. TAKAHASHI, S. Hashimoto and J. KANAEDA : Denpun Kagaku, 25, 155-161(1978).

8) Y. TAKASAKI : Agric. Biol. Chem., 49, 1091-1097 (1985).

9) Y. TAKASAKI : Agric. Biol. Chem., 47, 2193-2199 (1983).

10) N. SaIto : Arch. Biochem. Biophys., 155, 290-298 (1973).

11) H. OKemoto, S. Kobayashi, M. Monma, H. HASHIMOTO and K. HARA : Appl. Microbiol. Biotechnol., 25, 137-142 (1986).

12) N. Yoshigi, T. Chikano and M. KamimuRa : Agric. Biol.Chem., 49, 2379-2384 (1985).

13) K. Kainuma, K. Wako, S. Kobayashi, A. NoGAMI and S. SUZUKI : Biochim. Biophys. Acta, 410, 333-346 (1975).

14) Y. TAKASAKI : Agric. Biol. Chem., 46, 1539 (1982).

15) H. TANiguchi, C. M. JAE, N. Yoshigi and Y. MARUYAMA : Agric. Biol. Chem., 47, 511-519 (1983).

16) J. F. KENNEDY and C. A. White : Stärke, 31, 93-99 (1979).

17) J. F. RoByt and R. J. ACKERMAN : Arch. Biochem. Biophys., 145, 105-114 (1971).

18) K. Kainuma, K. WAKo, A. NogAMI and S. SUZUKI : Denpun Kagaku, 20, 112-119 (1973).

19) M. Somogyi : J. Biol. Chem., 195, 19-23 (1952).

20) K. KAINUMA and D. FRENCH : FEBS Lett., 5, 257-261 (1969).

21) W.E. TREvelyan, D. E. Procter and J.S. HARRISON : Nature, 166, 444-445(1950).

22) S. KobAYASHI, K. KAINUMA and D. FRENCH : Denpun Kagaku, 30, 62-68 (1983).

23) K. WeBer and M. J. OsBoRn : J. Biol.Chem., 244, 4406-4412 (1969).

24) C. M. WRIGLEY : Methods Enzymol., 22, 559564 (1971).

(Received October 22, 1990 ; accepted November 28, 1990)

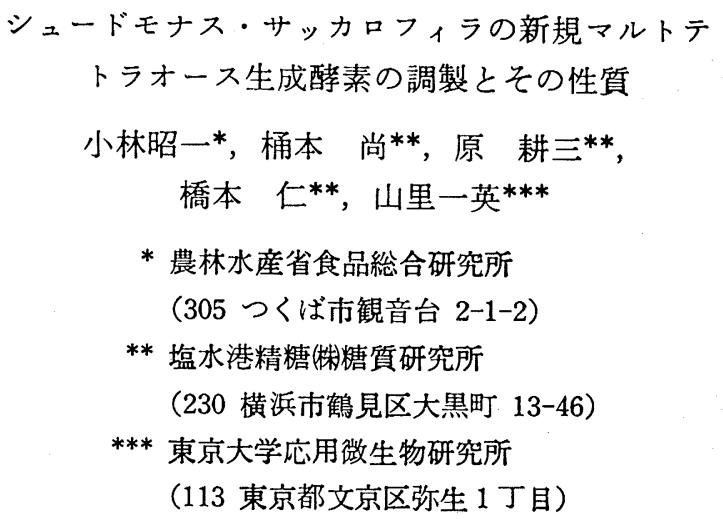

Pseudomonas saccharophila がマルトテトラオース 生成醅素を生産することを見い出した，本醉素を硫安分 画, DEAE-Toyopearl 650M と Toyopearl HW-55s の カラムクロマトにより精製した結果, 電気泳動的に単一 のピークを示す最終精製段階では $19 \%$ の回収率であっ た. 本醅素の分子量は 62,000 , 至適 $\mathrm{pH}$ および至適温 度は打の拈の 6.7 と $55^{\circ} \mathrm{C}$, 安定 $\mathrm{pH}$ 領域は 5. 5 10.5, $40^{\circ} \mathrm{C}$ まで安定であり, $\mathrm{CaCl}_{2}$ の添加により $45^{\circ} \mathrm{C}$ にまで

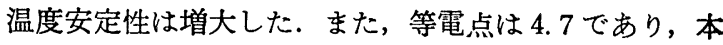
醉素活性は $\mathrm{Ag}^{+}, \mathrm{Hg}^{2+}, \mathrm{Co}^{2+}, \mathrm{Cu}^{2+}, \mathrm{Fe}^{3+}, \mathrm{Al}^{3+}, \mathrm{Zn}^{2+}$ な ぞの金属イオンにより阻害を受け, $\mathrm{Sr}^{2+}$ の添加により上 昇した.

本醉素は澱粉からマルトテトラオースを特異的に生成 し,グルコース, マルトース, マルトトリオース, マル トテトラオースには作用せず，反応は基質の非還元末端 から進行した。 また，アミロペクチンの分岐点を越えて の反応は困難であると推測された。 